\title{
Needs Analysis of Teaching Materials for Biology Learning Strategy Course
}

\author{
Ayu Dien Islamiyati1 ${ }^{1}$ Bowo Sugiharto1*, Baskoro Adi Prayitno ${ }^{1}$ \\ ${ }^{1}$ Department of Biology Education, Faculty of Teacher Training and Education, Universitas Sebelas Maret, Indonesia \\ DOI: $10.29303 /$ ippipa.v7iSpeciallssue.1194
}

\section{Article Info}

Received: November $14^{\text {th }}, 2021$

Revised: December 18th, 2021

Accepted: December 21st, 2021

\begin{abstract}
The aim of this study is to analyze the need for teaching materials in the Biology Learning Strategy course that are in accordance with the needs of lecturers and students to support learning in the modern era. The design of this research is exploratory research. The research subjects were ten lecturers in Biology Learning Strategy courses or similar courses from seven universities and 102 biology education students who had gone through Biology Learning Strategies courses from Universities in Surakarta and DIY. Data collection techniques are observation and questionnaires. Analysis of questionnaire data using Rasch modeling. The results of the study indicate that the obstacles faced in learning the Biology Learning Strategy course are the absence of teaching materials that can be used as a guide in the learning process. The results of the questionnaire analysis of lecturers and students are above the logit item value of 0.00 which shows the respondents agree on the importance of the Biology Learning Strategy course and that teaching materials are needed in the form of textbooks. The conclusion of this research is that it is necessary to develop a textbook with the characteristics of Blended Collaboration Problem-Based Learning to support the Biology Learning Strategy course.
\end{abstract}

Keywords: Textbooks; Learning strategies; Blended learning; Problem-based learning.

Citation: Islamiyati, A.D., Sugiharto, B., \& Prayitno, B.A. (2021). Needs Analysis of Teaching Materials for Biology Learning

Strategy Course. Jurnal Penelitian Pendidikan IPA, 7(Speciallssue), 340-344.

https://doi.org/10.29303/ippipa.v7iSpeciallssue.1194

\section{Introduction}

Every teacher is required to have good competence and capacity to improve quality of education in Indonesia in the 21st century. Educators must have adequate capabilities in designing all aspects related to learning activities. Students majoring in pedagogy must have the provisions to become competent teachers, including biology education students. One of the competencies that need to be trained by prospective biology teachers is pedagogic competence. An important pedagogic competence of biology teachers is biology teaching skills that are in accordance with the nature of biology as a science. Biology Learning Strategy is the right course for the biology education study program to equip students' pedagogic abilities as well as thinking skills (Sugiharto, 2019).

Learning strategy is a general pattern of teacherstudent actions in the realization of teaching and learning activities (Sanjaya, 2014). Biology Learning Strategy is designed to equip pre-service biology teacher in mastering and describing the basic principles of learning by using various approaches, strategies, and learning methods, as well as being skilled in designing learning scenarios and making lesson plans. In supporting the learning process of biology learning strategies appropriate teaching materials are needed with the characteristics of the current modern era. Teaching materials are arranged to support learning in accordance with the applicable curriculum, taking into account the needs, characteristics, and environment of 
students. Teaching materials are systematic learning materials and there are competencies that are used in the learning process with the aim of planning and reviewing the implementation of learning teaching materials are teaching materials in the form of systematic and complete competencies that will be used by students in the learning process to achieve learning objectives (Prastowo, 2012).

Learning in today's modern era, the use of the internet has become a basic need. Teachers are required to be able to master ICT-based learning so that the quality of education will continue to increase. In general, the Industrial Revolution 4.0 refers to the means of automation and data exchange in manufacturing technologies, including Physical-Cyber Systems, Internet of Things, big data and analytics, additive manufacturing, simulation, horizontal and vertical system integration, autonomous robots, and the cloud. (Tay, et al. 2018). The Industrial Revolution 4.0 has an impact on education in Indonesia. The education system in Indonesia needs to adapt to the needs of the Industrial Revolution 4.0 era. Therefore, learning innovations and learning curricula need to be designed to improve students' understanding of Information Technology (IT), Operational Technology (OT), Internet of Things (IoT), and Big Data Analytics (Iswan and Bahar, 2018; Hadiprayitno, et al., 2021).

One of the ICT-based learning models that can support the development of industrial revolution 4.0 is BCPBL. BCPBL is a learning model with a problembased learning platform (Problem Based Learning = PBL) by applying a collaborative approach and is implemented by combining face-to-face lectures in class and online lectures. In the BCPBL learning model, there are several syntaxes to solve and find solutions to problems in the real world. This learning model is one of the efforts that can improve the ability and capacity of educators in the Industrial Revolution 4.0 era through the Biology Learning Strategy course.

BCPBL learning model refers to the problembased learning model (PBL). According to Savery (2019), PBL is student-centered learning that empowers students to research, integrates theory and practice, and apply the knowledge to find problem solutions. PBL is a learning model in which the process of building students' knowledge and problem-solving from illstructured problems and discussion in groups to find the solution (Koçakoðlu, 2010; Temel, 2014). Problembased learning (PBL) is student-centered learning in which students learn about a subject by trying to find open-ended solution (Phungsuk, et al., 2017).

Blended learning is one of the impacts of the development of information technology in the 21st century. The age of globalization and information will rapidly affect the educational process. Sugiharto, et al. (2019)stated that one of the skills that are indispensable in this age of technology and information is the skill of mastering technology and information. Blended learning is a learning process that combines learning in face-to-face classes with learning using the internet or online (Irwandi, 2020). Lessons supported by chat, discussion, and various content on the platform. The beneficial aspects of face-to-face and online learning complement each other (Thorne, 2003).

The aim of this study is to analyze the need for teaching materials in the Biology Learning Strategy course that are inappropriate with the needs of lecturers and pre-service biology teachers to support learning in this era. The results of this study are expected to provide initial information about teaching materials that need to be developed. Furthermore, the results of this study are used to develop teaching materials for further research.

\section{Method}

This research is exploratory research by filling out a questionnaire. The developed questionnaire contains 20 questions each for lecturers and students regarding the learning experience and the need for teaching materials in the Biology Learning Strategy course with five aspects. Five aspects used are the learning process, learning facilities, characteristics of lecturers (students), and evaluation. The questionnaire used a four-point Linkert scale ranging from strongly agree (4), agree (3), disagree (2), and strongly disagree (1).

The respondents of this research were ten lecturers who teach Biology Learning Strategy courses (SPB) or similar courses from seven universities, namely UNS, UMS, UNY, UIN Lampung, UIN North Sumatra, Mataram University, UNEJ and biology education students who have gone through the Biology Learning Strategy course, which amounted to 102 students from universities in Surakarta and Yogyakarta.

The research data were analyzed using the Rasch model. The Rasch measurement model is used to analyze the data for both the quality of the instrument and the respondent's response. The results can explain the difficulty level of the item with the right measurement, detect item fit and identify item bias (called the item differential function or DIF). (Bond and Fox, 2015; Adams et al., 2021). Determine the quality of the instrument and respondents using the Winstep 3.73 application data mathematically converted to logit (logarithm units) through the participant's logarithmic function the probability of the response (Sumintono and Widhiarso, 2014). 


\section{Result and Discussion}

Based on the results of observations while learning the Biology Learning Strategy course, which took place online at Sebelas Maret University due to the impact of Covid19, it showed that the learning process was less than optimal. Learning resources in this course in terms of quantity are still limited in number, so students only rely on lecturers as a source of knowledge. In addition, some students do not have the provisions when participating in learning and are less active in finding references to relevant sources of information. The unavailability of teaching materials owned by students makes students have not prepared the material to be studied, so learning tends to go one way during discussions and questions and answers.

\section{Reliability}

The results of the analysis of the needs of teaching materials from the questionnaires of lecturers and students using the Rasch model, use the summary statistics, and the Wright map. Based on the results in the statistical summary of the lecturer's questionnaire (Table 1), information is obtained on the average logit person, which is 3.5 , which shows the average value of the respondents in the instrument of analysis of teaching material needs. The average value higher than logit 0.0 indicates a tendency for respondents to answer strongly agree and agree with the statements in all items. Cronbach's Alpha value in the lecturer's questionnaire obtained is 0.77 , meaning that the reliability obtained by this measuring instrument is good. This value is a measure of reliability which in practice is measured in the form of interactions between the person and the item as a whole. The value of person reliability is 0.79 , and item reliability is 0.71 .

Table 1. Results of the Rasch analysis of Lecturer

\begin{tabular}{lllll}
\hline & $\begin{array}{l}\text { Average } \\
\text { Logit }\end{array}$ & $\begin{array}{l}\text { Separa- } \\
\text { tion }\end{array}$ & $\begin{array}{l}\text { Reliabi- } \\
\text { lity }\end{array}$ & $\begin{array}{l}\text { Alpha } \\
\text { Cronbatch }\end{array}$ \\
\hline Person & 3.50 & 1.93 & 0.79 & 0.77 \\
Item & 0.00 & 1.57 & 0.71 & \\
\hline
\end{tabular}

Based on the results in the statistical summary of the student questionnaire (Table 2), information is obtained on the average logit person, which is 2.5, which shows the average value of the respondents in the instrument of analysis of teaching material needs. Analysis of summary statistics on student questionnaires (Table 2) Cronbach's alpha value of 0.84, which is included in the good category, the value of person reliability is 0.83 , and item reliability is 0.96

These results indicate that the data obtained in the research instrument test are in accordance with the requirements of Rasch modeling so that the student questionnaire instrument is reliable to use.

Table 2. Results of the Rasch analysis of Student

\begin{tabular}{lllll}
\hline & $\begin{array}{l}\text { Average } \\
\text { Logit }\end{array}$ & $\begin{array}{l}\text { Separa- } \\
\text { tion }\end{array}$ & $\begin{array}{l}\text { Reliabi- } \\
\text { lity }\end{array}$ & $\begin{array}{l}\text { Alpha } \\
\text { Cronbatch }\end{array}$ \\
\hline Person & 2.50 & 1.05 & 0.83 & 0.84 \\
Item & 0.00 & 1.00 & 0.96 & \\
\hline
\end{tabular}

\section{Teaching materials needed}

Based on the Wright Map, the lecturer and student questionnaires (Figures 1 and 2) show that the left column is the person column, and the right column is the items. Items that are above the average logit item value (+0.00 logit) mean that the item is relatively difficult to be approved by the respondent, and items that are below the average logit item value mean that the item is easily approved by the respondent. On average, respondents answered strongly agree on the aspects of the SPB Learning Process and Learning Facilities. This shows that the learning strategy course is considered very important by lecturers and students to produce competent prospective educators. According to the lecturer, the problem-based learning model is appropriate to be applied to this course. This is because the PBL is a learning model that can present real problems and solve various problems. Problem Based Learning (PBL) is student-centered learning in which students collaboratively produce solutions to real-life problems using existing knowledge and new information obtained by research or observation. (Tarhan and Ayyildiz, 2015).

In the aspect of learning facilities, the average respondent strongly agrees to use teaching materials in the form of textbooks that are in accordance with curriculum standards. Besides that, teaching materials for online learning combined with offline are needed to support SPB learning activities. The use of textbooks as a reference in learning will make students gain indepth material knowledge. This is in accordance with research by Amini, (2020), which shows that effective textbooks help improve students' competence in the domain of knowledge and character.

Textbooks are used as a systematic syllabus on subjects with content that is already available and supported by assignments and practice questions. Textbooks can save teachers time and effort in preparing course material. Textbooks also support students to learn at their own pace and give them a sense of independence and autonomy (O'Neill, 1982; Richards, 2001; Hung et al., 2018).

\section{Wright map}

In Figure 1. information is obtained, namely the item in the lecturer's questionnaire that is the most 
difficult for respondents to agree on is item number 6 (S6), which is the item with the highest logit value, besides that question no. 16 (S16) also has a fairly high logit, namely 1.71 . Figure 2 which is a wright map in the student questionnaire shows the items that are the most difficult to agree on or the items with the highest logit, namely item number 13 (S13) and item 6 (S6).

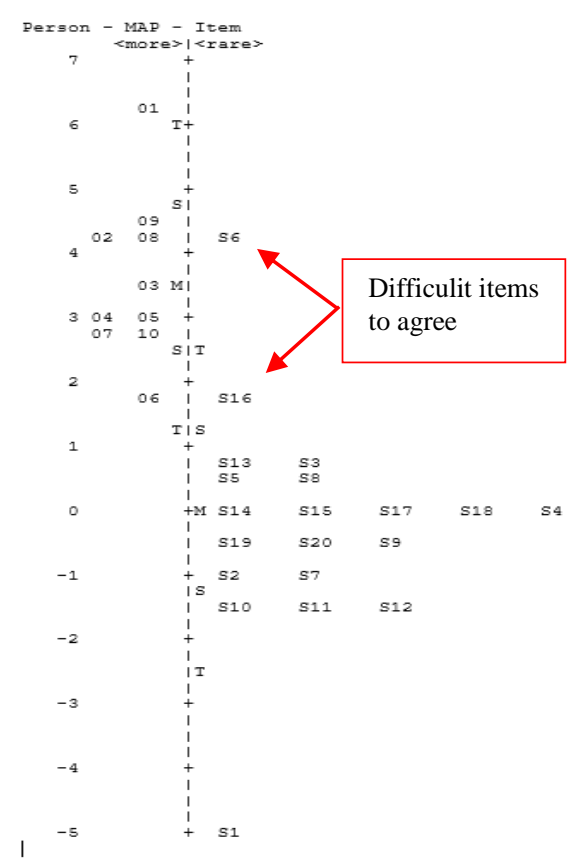

Figure 1. Wright Map of Lecturer's Questionnaire

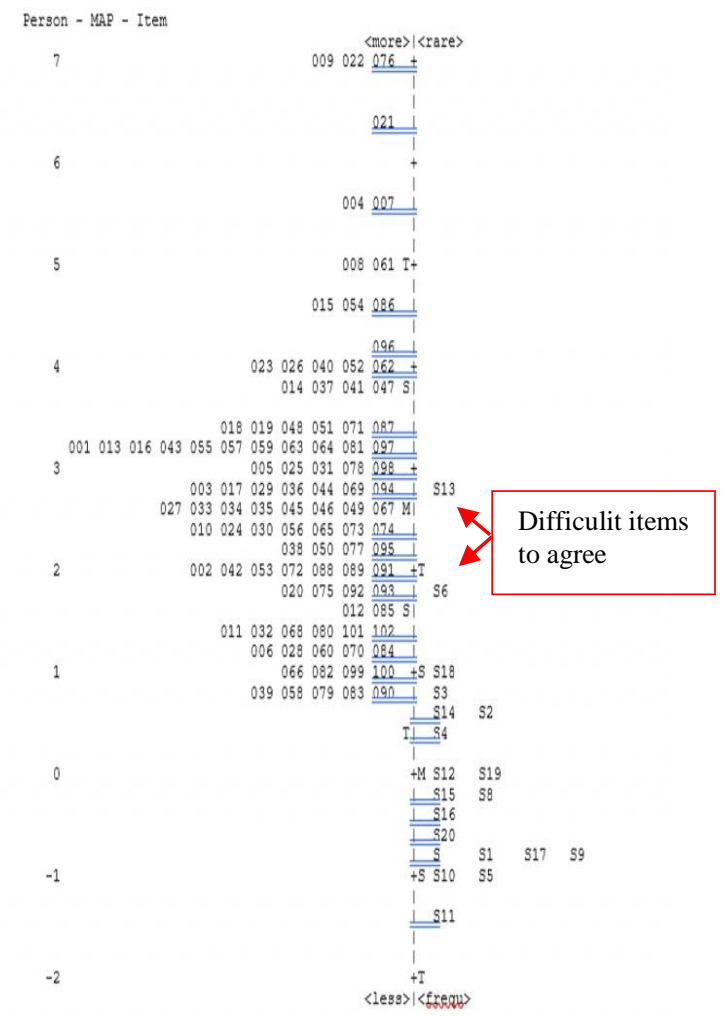

Figure 2. Wright Map of Student Questionnaire
The statement of items that are difficult for respondents to agree on can be seen in Table 3 .

Table 3. Difficult Items

\begin{tabular}{ll}
$\begin{array}{l}\text { Lecturer Questionnaire } \\
\text { Items }\end{array}$ & $\begin{array}{l}\text { Student Questionnaire } \\
\text { Items }\end{array}$ \\
\hline $\begin{array}{l}\text { Learning resources in SPB } \\
\text { courses are available and } \\
\text { meet curriculum standards } \\
\text { (S6) }\end{array}$ & $\begin{array}{l}\text { Online learning makes it } \\
\text { easier for students to } \\
\text { follow the learning process } \\
\text { Students always try to find } \\
\text { relevant reference sources } \\
\text { via the internet (S16) }\end{array}$ \\
$\begin{array}{l}\text { Learning resources in SPB } \\
\text { courses are available and } \\
\text { meet curriculum standards } \\
\end{array}$ & $(\mathrm{S} 6)$
\end{tabular}

This shows that learning resources in SPB courses are still limited in quantity, so lecturers and students need teaching materials that can be a reference in the learning process and make students active in finding relevant reference sources via the internet. The student questionnaire item 16 shows that some students have difficulty participating in online learning. This can be due to a pandemic situation that forces all learning to be done online only. However, on average, students answered agree on item 14 regarding the implementation of online learning combined with face to face or blended learning in SPB courses.

Study Ramadhani et al. (2019) show that implementing Problem Based Learning model using the Learning Management System (LMS) improves learning outcomes and student motivation in participating in learning. Mobile blended collaborative learning students can be given various authentic tasks or activities in which they can actively participate (Avci and Adiguze, 2020). Textbooks with problem-based learning models that are adapted to the characteristics of the 4.0 industrial revolution era, namely blended learning, have the potential to increase the competence of students majoring in biology education who will later become professional teachers who are ready to face challenges in the 21st century.

\section{Conclusion}

The results of this analytical study conclude that respondents who are lecturers of Biology Learning Strategy courses and students who have taken these courses to agree on the importance of the Biology Learning Strategy course and that teaching materials are needed in the form of books that are in accordance with the characteristics of the Industrial Revolution 4.0 era. From the data and information obtained, it is necessary to propose the development of teaching materials in the form of textbooks with the characteristics of Blended Collaboration Problem Based 
Learning to support the Biology Learning Strategy course.

\section{Acknowledgments}

Researchers would like to thank all those who have helped in this research especially the respondent.

\section{References}

Adams, D., Chuah, K. M., Sumintono, B., \& Mohamed, A. (2021). Students' readiness for e-learning during the COVID-19 pandemic in a South-East Asian university: a Rasch analysis. Asian Education and Development Studies, ahead-of-print(ahead-ofprint). https://doi.org/10.1108/AEDS-05-2020$\underline{0100}$

Amini, R. (2020). Textbook development on characterbased active learning strategy using tournament type for elementary School student. Journal of Physics: Conference Series, 1567(4). https://doi.org/10.1088/17426596/1567/4/042036

Avci, H., \& Adiguzel, T. (2017). A Case Study on Mobile-Blended Collaborative Learning in an English as a Foreign Language (EFL) Context. The International Review of Research in Open and Distributed Learning, 18, 45-58. https:// doi.org/10.19173/irrodl.v18i7.3261.

Hadiprayitno, G., Lestari, A., Lukitasari, M., \& Sukri, A. (2021). Blended Learning Station-Rotation Model: Does it Impact on Preservice Teachers ' Scientific Literacy? $7(3)$. https://doi.org/10.29303/jppipa.v7i3.676

Hung, K., Lam, T., Hon, B., Nkhoma, M., Richardson, J., \& Thomas, S. (2018). Computers \& Education The role of textbook learning resources in e-learning: A taxonomic study. Computers \& Education, 118(October 2017), 10-24. https://doi.org/10.1016/j.compedu.2017.11.005

Irwandi. (2020). Strategi Pembelajaran Biologi. Pustaka Reka Cipta. [Indonesian]

Phungsuk, R., Viriyavejakul, C., \& Ratanaolarn, T. (2017). Development of a problem-based learning model via a virtual learning environment. Kasetsart Journal of Social Sciences, 38(3), 297-306. https://doi.org/10.1016/j.kjss.2017.01.001

Ramadhani, R., Umam, R., Abdurrahman, A. \& Syazali, M. (2019). The Effect of Flipped-Problem Based Learning Model Integrated With LMS-Google Classroom for Senior High School Students. Journal for the Education of Gifted Young Scientists , 7 (2), 137-158. https:// doi.org/10.17478/jegys.548350
Standar Proses Pendidikan. Prenadamedia. [Indonesian]

Savery, J. R. (2019). Comparative Pedagogical Models of Problem - Based Learning.

Sugiharto, B., Maret, U. S., \& Corebima, A. D. (2019). The Pre-Service Biology Teacher Readiness in Blended Collaborative Problem Based Learning ( BCPBL ). International Journal of Instruction, 12(4). https://doi.org/10.29333/iji.2019.1248a.

Sumintono, B., \& Widhiarso, W. (2014). Aplikasi Model RASCH untuk Penelitian Ilmu-Ilmu Sosial. Trim Komunikata Publishing House. [Indonesian]

Tarhan, L., \& Ayyildiz, Y. (2015). The views of undergraduates about problem-based learning applications in a biochemistry course. Journal of Biological Education, 49(2), 116-126. https://doi.org/10.1080/00219266.2014.888364

Tay, S. I., Lee, T. C., Hamid, N. Z. A., \& Ahmad, A. N. A. (2018). An overview of industry 4.0: Definition, components, and government initiatives. Journal of Advanced Research in Dynamical and Control Systems, 10(14), 1379-1387.

Temel, S. (2014). The effects of problem-based learning on pre-service teachers ' critical thinking dispositions and perceptions of problem-solving ability. South African Journal of Education, 34(1), 120. https://doi.org/10.15700/201412120936.

Thorne, K. (2003). Blended Learning: How to Integrate Online and Traditional Learning. Kogan Page. 